\title{
VÉGTELEN TARTALÉK \\ Térbeli fedezet az építészeti szabályozásból kiinduló tervezésben
}

\author{
Weiszkopf András \\ Budapesti Müszaki és Gazdaságtudományi Egyetem, Lakóépülettervezési Tanszék, \\ 1111 Budapest, Müegyetem rakpart 3. \\ e-mail: weiszkopf.andras@lako.bme.hu
}

\section{Bevezetés}

Az építést, mint valamennyi közügyet, szabályok sokasága hatja át. Az építészeti alkotási folyamat jellege, hogy az építést magát egy átfogó tervezési fázis előzi meg. Az építész ebben az időszakban a megbízóval összeállított programnak és az építési helyen szabott megkötéseknek megfelelő épületet tervez. Jelen kézirat az épületek tervezését befolyásoló szabályok, és az azokra válaszul kialakuló tervezési módszertanok viszonyát vizsgálja, továbbá azt, hogy a szabályok összetettsége és számossága milyen hatással lehet az építészet térbeliségére és annak minőségére. Célja egy új nézőpont felvétele, mely az építést szabályozó szabályrendszerre, mint lehetséges gondolati kiindulópontra tekint a tervezés során.

\section{Szabályok}

A jogszabályok olyan helyzetek rendezésében szükségesek, amelyekben érdekellentétek állnak fenn és megoldásuk közérdek. Az épületeknek ebben az értelmezésben meg kell felelniük a használókkal szemben életvédelmi kívánalmaknak, mindenki mással szemben pedig településképi elvárásoknak.

Magyarországon az OTÉK illeszkedési kötelmei, az Országos Tűzvédelmi Szabályzat elöírásai meghatározóak egy új épület tömegformálására, anyaghasználatára és megjelenésére. A Helyi Építési Szabályzatok zöldterületi mutatókkal, beépítési százalékkal megadják az építési telekkel területarányos minimális zöldfelület és maximális megépített épület méretét, a szintterületi mutatóval meghatározzák egy építési övezetben építhető szintek számát, továbbá egyéb geometriai megkötésekkel szabják meg egy építési övezetbe felhúzható épületek tömegformálását. A települések Településképi Arculati Kézikönyvei és településkép védelmi rendeletei részletesebb javaslatokat és előírásokat tartalmaznak az építendő épületek színére, részletmegoldásaira vagy akár a nyílászárók és a kerítések kialakítására vonatkozóan.

Léteznek azonban ettől eltérő logikájú szabályozási modellek is. New York Manhattan kerületében 1916-ban kezdték el az épület magasságát és geometriáját szabályozni. Addig az épületek méretét a technológia és annak gazdasági vonzatai, geometriájukat pedig az építési telek geometriája korlátozták. Az 1902-ben Daniel Burnham és Frederick Dinkelberg tervei alapján felépült Flatiron Building a ház összes szintjén a telek beépíthetö kontúrját ismétli. A hasonló gondolatmenet mentén tervezett korabeli magasházak - mint az Equitable Building és Singer Tower - között az utcák szük légtérarányú sikátorokká alakultak. Az új szabályozás szerint Manhattanben az építési telek területének negyedén lehetett csak magasságkorlátozás nélkül tornyot építeni, a telek fennmaradó részén az utcák középvonalára szerkesztett ferde síkok által határolt formánál nem nagyobb kiterjedésü épülettömeget lehetett csak létrehozni. A szigorúnak számító geometriai megkötések új tervezésmódszertant indukáltak, mely a maximálisan felépíthető épülettömeget vette kiindulási alapnak (Ferris, 1922), amit a használhatóságnak és a rendelkezésre álló építési technológiáknak megfelelően lépcsősített és 
bevágásokkal csonkított. Ferris felismerte és kifejtette a szabályozás által konstruált épülethéj alakításában rejlő variációs lehetőségeket, cikkével évtizedekre meghatározza a kontinens magasház-építészetét. Az új szabályozás és a Ferris által publikált tervezésmódszertan megfigyelhető az 1931-ben Shreve, Lamb \& Harmon tervei alapján megvalósult Empire State Buildingen, és a telekosztáshoz képest tornyokkal szellösen tűzdelt manhattani várossziluetten.
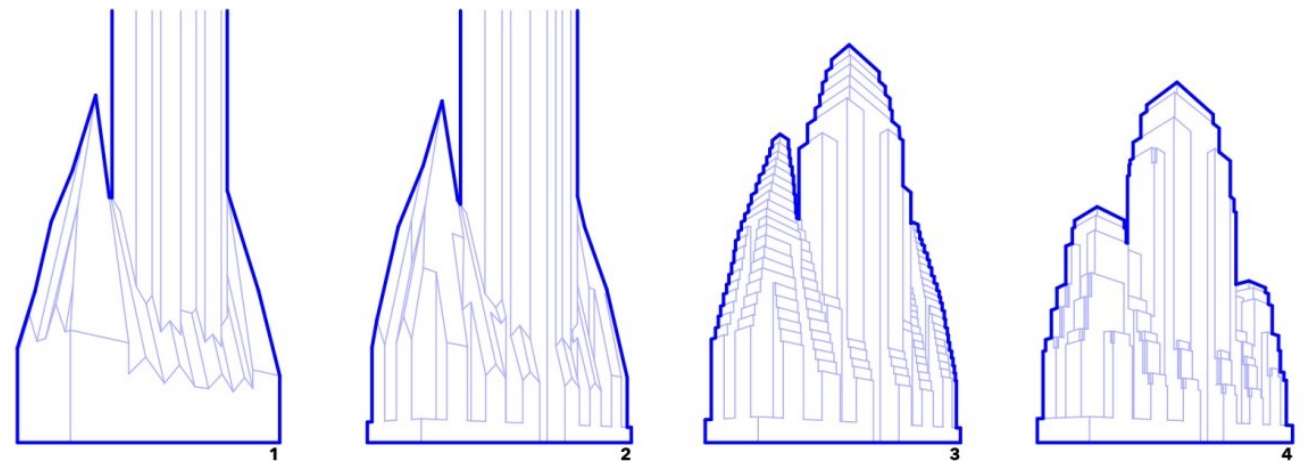

1. ábra: Hugh Ferris manhattani épület tervezési diagramja, a szabályozás által konstruált épülethéjjal (1) és a végleges épülethez (4) vezető lépésekkel (2) (3) (Ferris, 1922 alapján).

\section{Után-szabályozás}

A szabályozási környezet kialakítása egyenlőségelvü: senki nem szerezhet előnyöket más kárára. Ezt a funkcióját geometriai és térbeli korlátok szabásával, telekhez viszonyított kiterjedésbeli arányszámok maximalizálásával, anyagok és színek meghatározásával, építészeti eszköztárak szükítésével, biztonsági minimumok definiálásával látja el.

Az építési szabályozás az építés rendjét, módját, jellegét és müködését határozza meg. Létezése feltételezi, hogy a rendszer, amit szabályoz, valamilyen ok miatt nem képes önszabályozásra. Az építtetők szabályok nélkül - maguktól - túl nagyot, túl magasat, túl sokat, túl idegent építtetnének maguknak. Az építész tervezőknek is szükségük van szabályokra, azok nélkül ugyanis, maguktól, túl nagyot, túl magasat, túl sokat, túl idegent terveznének megbízóiknak. A szabályozás együtt jár a megfeleltetéssel, jelen értelmezésben az építészetet térbeliségét korlátozza és köti meg. Magában hordozza, hogy létezik egy olyan építészet, ami nem felel meg a szabályoknak, így leválasztva az építészet, mint a tereket létrehozó cselekedet, egy részét a valóságos építésről. Az építész tervező eszerint egy olyan alkotó, aki a szabályok struktúráját navigálni tudja. Ha az építészetének egy darabja éppen a leválasztás rossz oldalára esik akkor képes azt a túloldalra, a megvalósíthatóság oldalára utólag átterelni, vagy jobb esetben pont arról az oldalról választ. Így indirekt módon a szabályrendszer a lehetséges építészeti gondolatokon belül leválaszt egy kisebb - megépíthetö gondolatokat tartalmazó - halmazt.

\section{Determináltság}

Jogszabályok egyszerre összetett és szerteágazó struktúrájának köszönhetően az építészetnek az a hányada, amely egy adott helyen egy adott használatra megvalósítható kikutatható és azonosítható. Bár a terek alkotásának és funkcióval való megtöltésének végtelen számú módja és kimenetele van, mégis, ha építeni szeretnénk, az építés tárgyának be kell tartania a szabályokat. Így minden építésre való vállalkozás egyben előrevetíti a szabályoknak való megfelelés kényszerét és ígéretét is. 


\section{A hely okozta determináció}

Egy adott építési helyre adottak az ott érvényes építési elöírások, mind helyi rendeletekből mind országos törvényekből, amik a geometriai megkötések miatt egy adott épülethéjat konstruálnak. Ennek pontossága, részletezettsége, esetenként ellentmondásossága, épületszerüsége a helytől és a vonatkozó szabályoktól függően változik. Az épülethéj absztrakt, kidolgozatlan. A részletek kibontása az építész feladata. A generált épülethéj határfelületként müködik, a leendő épület befoglaló méretének, tömegének maximumát adja meg.

Arno Brandlhuber tervezési munkáit az előírások rendszeréből indítja, A Brunnenstrasse 9 (2010) galéria és mühelyépület tervezésének idején Berlin Városépítészeti Osztályán a kritikai rekonstrukció volt a követendő tervezői magatartás. Brandluhuber viszont a szomszédos épületek vizualitása helyett azok térbeliségét vette az épület tervezési alapjául. A két szomszédos épület zárópárkánya és födémjei közötti 30 centiméter eltérés áthidalása határozza meg a Brunnenstrasse 9 utcai homlokzatát, az építész saját állítása szerint így a belvárosi illeszkedés egy új tipológiáját hozta létre. A valóságban az épület tömegalakításában folyatja a szomszédjai által mutatott mintát, ám alkatrész szerü esztétikájával új minőséget hoz az utcaképbe. Fontossága, hogy az illeszkedési megkötésekből táplálkozva a hagyományostól eltérö, új nyelvezetủ építészetet tudott alkotni, példaként szolgál a megkötések közötti építészeti müködésre.

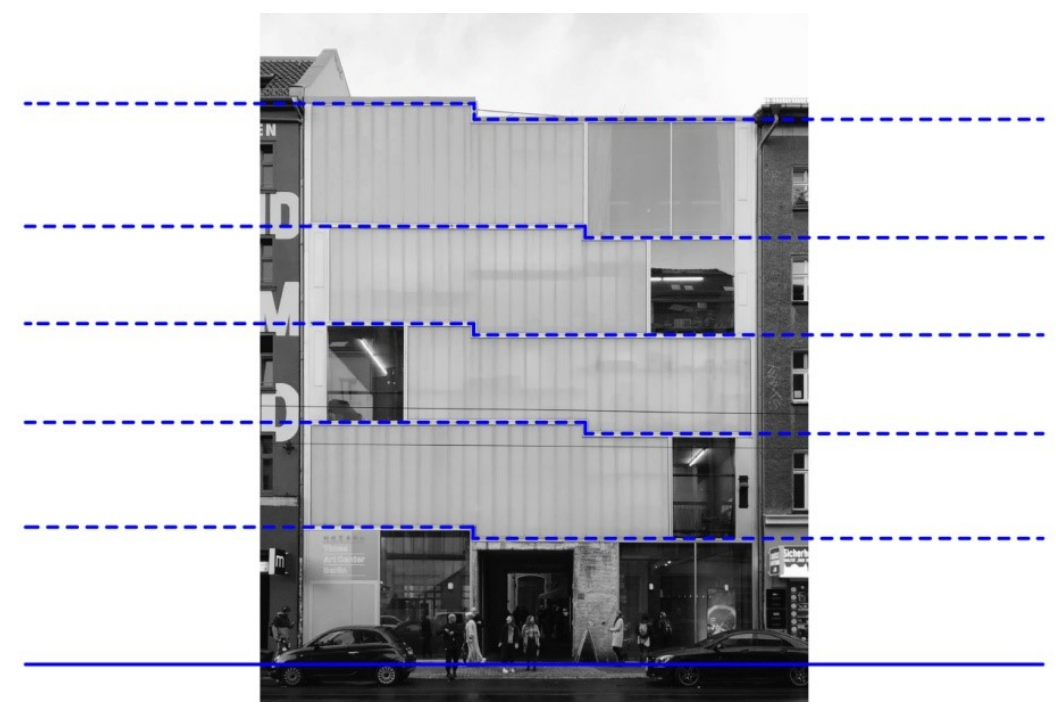

2. ábra: Brandlhuber+ Emde, Burlon (2010): Brunnenstrasse 9, Berlin, Németország, a szomszédos épületek párkány és födémszintjeinek jelölésével.

A BME Lakóépülettervezési Tanszéken folyó, helyspecifikus energetikai tervezés lehetőségeit vizsgáló kutatás (Kolossa et al., 2013) tézise szerint az eltérö építési helyekhez tartozó eltérő mikro klimatikus viszonyok felmérhetőek és ezekkel energetikai hatékonyság és használhatóság szempontjából tervezni lehet. Kolossa József DLA vezetőtervezővel készített Kürt utca 8. társasház koncepciótervi fázisánál az épület tervezéséhez meghatározó adatot szolgáltatott egy helyspecifikus energetikai mérés. Segítségével megállapítottuk azt a térbeli síkot, ami alatt a helyszínen nem lehetséges a napsugárzásból energiát nyerni. Ezt az információt felhasználva konstruáltuk meg az épület használati struktúráját: a garázsbeálló került a homlokzat bal oldalára, ahova közvetlenül nem süt oda a nap, míg a föbejárat és a földszinti közhasználatú helyiségek megnyitása a homlokzat jobb oldalán van, így a reggeli napfény elérhető maximuma hasznosul. Elképzelhető tehát, hogy egy épület fizikai tömegére 
nem kizárólag jogszabályi determinációk hatnak, hanem az építési telekből származtatott energetikai megkötések és lehetőségek is.

\section{A használat okozta determináció}

Adott építési helyre a használati térigény meghatároz egy térbeli formát. Ez funkcionális igények kielégítése szempontjából egy használhatósági términimumot jelent, egy térbeliség méretének alsó határát, belsőtéri kiterjedési minimumát. A használati térstruktúra tömörséghez konvergál alaprajzi mérettől függetlenül, az építészeti alkotás igyekszik a lehető legtöbb használati értéket nyújtani a lehetö legkevesebböl. A funkcionális tömörség ellentéte nem a lazaság, hanem a terjengősség.

A használati térigények változását jól szemlélteti a Frankfurti Konyha. A ma ismert és használt konyhák prototípusát Margarete Schütte-Lihotzky osztrák építész készítette el. Ernst May, Frankfurt fóépítészeként, az ambiciózus Új Frankfurt terv keretében 1930-ra 10000 új szociális lakást akart építeni. Felkérte Schütte-Lihotzkyt a hagyományos konyha tökéletesítésére, egy új, funkcionálisabb és helytakarékosabb konyhamodell kidolgozására, amit az újonnan épült lakások mindegyikébe beterveznének. Schütte-Lihotzky a konyha tervezését úgy fogta fel, mint egy üzem vagy munkahely tervezését, amibe bevonta a kortárs ergonómiai és higiéniai ismereteket is. Elgondolása szerint a konyha minél hatékonyabban üzemel, a nőnek annál kevesebb időt kell ott töltenie, és így több időt tölthet a családjával. Schütte-Lihotzky végül három alig különbözö bútorozási modellt tervezett, melyek minimális helyigénye $1,87 \times 3,44$ méter volt.

A terek használati térigény alapján való méretezése a huszadik század kezdetén újdonságnak számított. Az első világháború utáni újjáépítésben költségcsökkentési, higiéniai és üzemeltetési indíttatásból a kor funkcionalista építészei kutatták és igyekeztek megállapítani a lakhatási téri minimumot (Lestikow, 1929) ami a mai napig irányelvként, kiinduló alapként szolgál minimális térigények meghatározásában. Ma már tudjuk, hogy a térhasználatot és ezáltal a szükséges térméreteket a használók kulturális mintázatai szintén meghatározzák, így a kortárs tervezett térméretek jellemzően ezzel is számolnak.
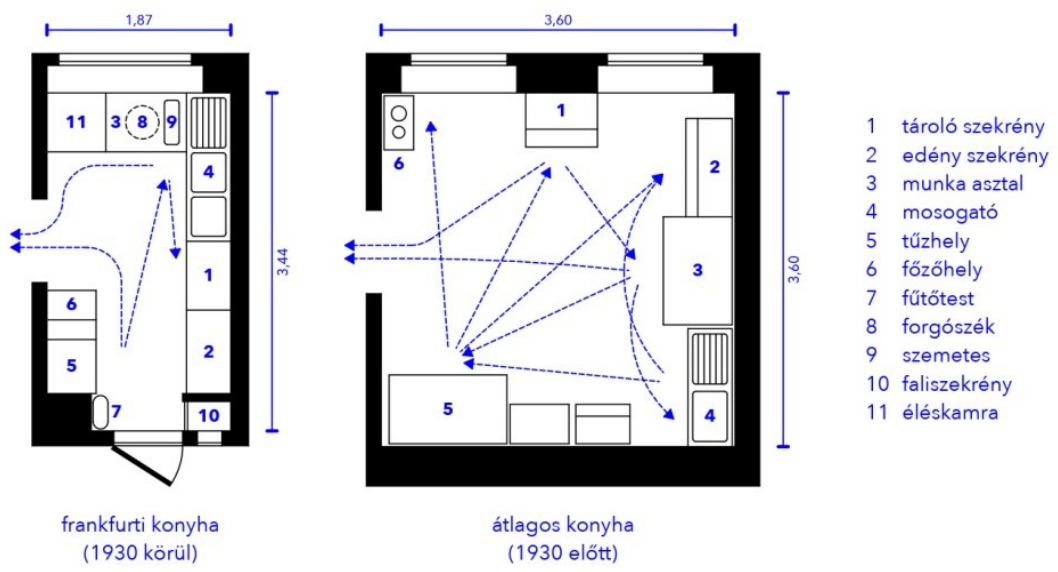

3. ábra: A frankfurti konyha és egy átlagos korabeli konyha berendezései, mérete, ergonómiája és használata összevetve.

Az építés a rendelkezésre álló terekben nem kielégíthető térigények felmerülésekor történik. Ilyenkor olyan épület létrehozása a cél, amely a felmerülő igények minimális kiszolgálására alkalmas térsorokat legalább tartalmazza. Ezek a térigények előre megállapíthatóak. Különböző típusú használatok, különböző arányú tereket igényelnek. A térigény minél összetettebb, minél több különböző típusú térre van szükség, annál jobban 
csökken a lehetséges használati térstruktúrák száma és növekszik az előre meghatározott jelleg.

\section{A tartalék}

Abban az esetben, ha az építészeti alkotási folyamat eredménye egy, az építésre vonatkozó szabályoknak és az épületet használók használati igényeinek megfelelő épület felépítéséhez szükséges tervdokumentáció, akkor ezen feltételek minimális kielégítésére elegendő a szabályozás által konstruált épülethéjnál kisebb vagy egyenlő befoglaló tömegü - és az elöírások minőségi elvárásait teljesítő - épületet tervezni, és ebben a minimális térbeli funkcionális igényeknek helyet biztosítani. Konstruált épülethéj és determinált térstruktúra különbségéből adódik egy térrészlet amire - a korábbi teljesülésük miatt - nem vonatkoznak építéssel és használhatósággal kapcsolatos szabályok. Ez a tartalék.

A tartalék a tervezési program többlete. Egy olyan fennmaradó térdarab, amivel nem bír sem köz, sem magánérdek. A tér tartalék felhasználása, a többi érintett által nem ismert esetlegességek tekintetbe vétele, a vele való elszámolás ezért az építész kiemelt felelőssége. A tartalék az a térrészlet, amiben az alkotónak lehetősége van építészeti minőséget és karaktert létrehozni. A tartalék a térképzés tere.

A generált épülettömeg és a determinált használati térstruktúra között fennmaradó térrészlet mérete rendkívül sok tényezőtől függ. Három alapeset mégis elkülöníthető: az első esetben az épülethéj nagyobb, mint a használati térstruktúra és létrejön a tartalék; a második esetben a determinált épülethéj kisebb, mint a használati térstruktúra és az épület funkcionális korlátozások nélkül nem tud létrejönni; harmadik, amikor a két térbeli forma megközelíti egymást, határoló felületük megegyezik, a tartalék a térbeliség felületén jelenik meg. Az építészeti minőség minden esetben megjelenhet az alkotáson, a tartalék bármekkora lehet, kivéve a nulla.

\section{A végtelen}

A tartalék tér létezése és az építészet térbeli minőségéhez való viszonya alapján megállapítható, hogy a generált épülethéjat létrehozó szabályrendszer szempontjai és a szempontok számossága a tervezendő épületre nincsenek korlátozó hatással. A generált épülethéjat a tervezési módszertan irányából vizsgálva tetszőleges módon is létre lehet hozni, ami így végtelen számú új szempontot is be tud fogadni a tartalék megszünése nélkül, olyanokat is, amelyek az épületek és a települések fenntarthatóságához hozzájárulnak.

\section{Hivatkozások}

Ferris, H., 1922: The New Architecture. The New York Times Magazine, 1922. március 19. 8-9p. 27. forrás: https://archive.nytimes.com/ (utolsó letöltés: 2019. 07. 06.)

Kolossa, J., Weiszkopf, A., Mészáros, R., Mangel, Z., 2013: 4. Energetics and location. Energy-efficient, site-specific planning. (szerk.: Perényi T.) BME Lakóépülettervezési Tanszék. forrás: https://www.tankonyvtar.hu/hu/tartalom/tamop412A/2011 0055_energy_efficient/index.html (utolsó letöltés: 2019.10.30.)

Lestikow, H., 1929: Die Wohnung für das Egsitenzminimum. Druckerei August Osterrieth, Frankfurt A.M. 270. 